\title{
Effect of Foliar Application of Zinc on Growth and Yield of Guava (Psidium Guajava L.)
}

\author{
Imran Arshad $^{1 *}$, Wajiha $\mathrm{Ali}^{2}$ \\ ${ }^{1}$ Agriculture Engineer, Star Services LLC, Al Muroor Road - Western Region of Abu Dhabi, United Arab Emirates (UAE). \\ ${ }^{2}$ Horticulturist, Agriculture Department, SGS Pakistan Pvt. Ltd, Karachi, Sindh - Pakistan.
}

\begin{tabular}{l} 
A R T I C L E I N F O \\
\hline Article history: \\
Received: 29 March 2016 \\
Accepted: 23 April 2016 \\
Online: 25 April 2016 \\
\hline Keywords: \\
Guava \\
Zinc \\
Foliar Fertilizer \\
Agriculture \\
Sindh \\
Pakistan
\end{tabular}

\begin{abstract}
A B S T R A C T
In depth study focusing to ascertain the effect of different rates of Zinc ( $\mathrm{Zn}$ ) fertilization in improving the quality and yield of Guava fruit was carried out at Gharo, Sindh - Pakistan during year 2014-15. The outcome of the research revealed that there was no significant effect on the yield as well as quality, without using foliar Zn fertilizers. However, after application of the arrangement of foliar fertilizer the quality and production of fruits was significantly increased. The fruit yield in terms of plant height $(3.111 \mathrm{~m})$, length of fruit $(6.989 \mathrm{~cm})$, breadth of fruit $(6.070 \mathrm{~cm})$, weight of fruit $(111.555 \mathrm{gm})$, number of fruits per plant (379.679), fruit yield (41.935 kg/plant) was recorded maximum in plants which were treated with $\mathrm{Zn}_{5}(0.5 \%)$. Same treatment also showed the superior fruit quality traits evaluated in terms of TSS (9.373\%), Vitamin C (45.147 $\mathrm{mg}$ per $100 \mathrm{ml}$ of juice), and Firmness $\left(5.969 \mathrm{~kg} / \mathrm{cm}^{2}\right)$ with lower acidity $(0.485 \%)$. Nearly same results were achieved by $\mathrm{Zn}_{6}(0.6 \%)$ and $\mathrm{Zn}_{7}(0.7 \%)$ treatments but statistically some parameters recorded less. However, plants with no foliar application showed un-satisfactory results regarding all the parameters. Too low or high concentration of Zinc solution may reduced the yield and yield parameters of guava.
\end{abstract}

\section{Introduction}

Crop yield in Pakistan is not satisfactory due to improper fertilizer management. Balanced nutrients are paid little attention. Its deficiencies emerge in the farmer's field and are recognized as the symptoms on foliage and reduction in the quality and yield. Foliar fertilizers are being used in vegetable and fruit crops that contain various macro and micronutrients [1]. This technology has come under use but is not common. Foliar Feeding is a technique for feeding plants by applying liquid fertilizer directly to their leaves. It is not a substitute for maintaining adequate levels of plant nutrients in the soil but can be beneficial in certain circumstances.

Most commonly, it is recommended for alleviating specific micronutrient deficiencies [2]. In recent years, products have been developed that contain growth hormones, natural plant sugars, microorganisms and other ingredients. The most effective means of foliar application is the use of spray equipment. Either low pressure or high pressure equipment may be used. Spray equipment provides better placement, less loss by dripping and more effective coverage of the foliage than most other methods of application [3].

The hose-end applicator may be used also. It does not provide as accurate coverage as the spray equipment does. It also results in

"Corresponding Author: Imran Arshad, Star Services LLC, A1 Muroor Road Western Region of Abu Dhabi, (UAE), Cell No. 00-971-52-9931586,

engr_imran1985@yahoo.com

www.astesj.com

https://dx.doi.org/10.25046/aj010103 greater loss of plant nutrients as it has a broader coverage than other types of spray. However, its lower cost, lower maintenance and ease of use often offset these disadvantages, especially for the home gardener [4]. For most fertilizer materials this is 2 to 4 pounds of the fertilizer in 100 gallons of water. Urea may be used at $12 \mathrm{lbs} / 100$ gallons, sodium molybdate or molybdic acid at the rate of $2 \mathrm{lbs} / 100$ gallons but only 4 to 8 ounces per acre of these are needed for plant growth. Borax or other Boron sources should be used at only 1 to $2 \mathrm{lbs} / 100$ gallons of water. The chelate sources of iron, zinc, copper and manganese are used at 2 to $3 \mathrm{lbs} / 100$ gallons of water. According to literature survey, many reports are available about foliar fertilizers on many plants as chrysanthemum, rose, tuberose and iris plants [9]. The present research was carried out to evaluate the impact of foliar application of Zinc on the growth, yield and development of Guava (Psidium Guajava L.).

\section{Materials and Methods}

Field experiment were carried out during 2014 and 2015 on a sandy loamy clayey soil at Gharo, Sindh - Pakistan. The soil moisture and temperature regimes at the site were Aridic and Thermic, respectively. An experiment was laid out in a complete Randomized Block Design with nine treatments and three replications. The existing guava plants (Allahabad variety) were studied in this research work and which were transplanted at a spacing of $6 \mathrm{~m}$ x 8m during February 2009 on an area of 2 acres. The fruit trees were all planted at the same time and at the start of 
the experiment, they were more than 5 years old. The irrigation method was traditional flood irrigation throughout each year of the experiment. The water samples had been collected for the conductance of different water tests. Likewise, the samples of the soil were collected from different zones at 6 inch and 12 inch depth for different laboratory tests purposes on composite basis. The results of the soil and water samples are given in Table 1 and Table 2 respectively.

Table 1. Analysis Results of Soil (at 6 and 12 inch depth on composite basis)

\begin{tabular}{|c|c|c|}
\hline $\begin{array}{c}\text { Parameter } \\
\text { s }\end{array}$ & \multicolumn{2}{|c|}{ Test Results } \\
\hline & $\begin{array}{c}\text { Sample 01 } \\
\text { (06 inch depth) }\end{array}$ & $\begin{array}{c}\text { Sample 02 } \\
\text { (12 inch depth) }\end{array}$ \\
\hline $\mathrm{pH}$ at $25^{\circ} \mathrm{C}$ & 8.07 & 8.12 \\
\hline $\mathrm{EC}$ & $1.81 \mathrm{ds} / \mathrm{m}$ & $1.91 \mathrm{ds} / \mathrm{m}$ \\
\hline Nitrogen & $87.76 \mathrm{mg} / \mathrm{kg}$ & $83.3 \mathrm{mg} / \mathrm{kg}$ \\
\hline Phosphorus & $54.23 \mathrm{mg} / \mathrm{kg}$ & $80.75 \mathrm{mg} / \mathrm{kg}$ \\
\hline Potassium & $95.12 \mathrm{mg} / \mathrm{kg}$ & $119.01 \mathrm{mg} / \mathrm{kg}$ \\
\hline SAR & 1.41 & 0.422 \\
\hline Zinc & $0.46 \mathrm{mg} / \mathrm{kg}$ & $0.54 \mathrm{mg} / \mathrm{kg}$ \\
\hline
\end{tabular}

Table 2. Analysis Results of Water

\begin{tabular}{|c|c|}
\hline Parameters & Test Results \\
\hline $\mathrm{pH}$ at $25^{\circ} \mathrm{C}$ & 7.55 \\
\hline $\mathrm{EC}$ & $3.85 \mathrm{ds} / \mathrm{m}$ \\
\hline $\mathrm{SAR}$ & 7.97 \\
\hline $\begin{array}{c}\mathrm{CaCO}_{3} \\
\mathrm{Hardness}\end{array}$ & $852.90 \mathrm{mg} / \mathrm{l}$ \\
\hline $\mathrm{HCO}_{3}$ & $300.17 \mathrm{mg} / \mathrm{l}$ \\
\hline $\mathrm{TDS}$ & $2636.00 \mathrm{mg} / \mathrm{lit}$ \\
\hline
\end{tabular}

Chemical analysis of the irrigation water indicated relatively high salinity of the irrigation water with an $\mathrm{ECw}$ of $3.85 \mathrm{dS} / \mathrm{m}$. Since, Guava is moderately salt tolerant and the soil texture was sandy loamy Clay throughout the profile, fruit production generally has been economical. Soil analysis of the experimental field indicated $\mathrm{Zn}$ deficiency. On the basis of results obtained the type and amount of fertilizers applied per tree were Urea (twice, $350 \mathrm{~g}$ each time), Triple Super Phosphate (300 g), and Potassium Sulphate $(300 \mathrm{~g})$ accordingly. The treatments provided to the plants in two split phases i.e. half dose after last harvest and half before the fruiting of upcoming guava yield in September.

Fertilizer applied between the radial distances 200 to $260 \mathrm{~cm}$ away from trunk, $15-25 \mathrm{~cm}$ deep and then properly covered with soil. There is no clear recommendation for $\mathrm{Zn}$ nutrition of Guava in the area and there is doubt about its efficiency under saline conditions. $\mathrm{Zn}$ was foliar applied thrice, using a pesticide application machine at different Zinc concentration i.e. $Z_{0}$ (control - no Zinc), $\mathrm{Zn}_{1}(0.1 \%), \mathrm{Zn}_{2}(0.2 \%), \mathrm{Zn}_{3}(0.3 \%), \mathrm{Zn}_{4}$ $(0.4 \%), \mathrm{Zn}_{5}(0.5 \%), \mathrm{Zn}_{6}(0.6 \%), \mathrm{Zn}_{7}(0.7 \%)$ and $\mathrm{Zn}_{8}(0.8 \%)$, when the branches had produced young leaves, in both years of the experiment. The source of $\mathrm{Zn}$ was dry zinc sulfate $\left(\mathrm{ZnSO}_{4} ; 34 \%\right.$ $\mathrm{Zn}$ ). For recording the fruit quantity and quality observations five mature fruits were randomly selected from each observational plant and same fruits were used for recording the various physicochemical properties of guava. The data were statistically evaluated by using SAS software. Duncan's multiple range test at $5 \%$ level of probability was used for comparison of means.

\section{Results and Discussion}

The subject research was carried out to check the fruit yield and growth rate of guava in a saline land conditions with the application of constant rates of NPK fertilizers along with different rates of Zinc fertilizer to all plants under study. The subject study revealed that guava plant height, length of fruit, breadth of fruit, weight of fruit, number of fruits per plant, fruit yield, $\mathrm{TSS} \%$, Acidity, Vitamin C, and Firmness differed very significantly between application of different rates of Zinc fertigation as mentioned in Table 3. The critical gathered observations and data for the above discussed parameters during the subject research are appended below:

\subsection{Plant Height}

Statistically remarkable results were observed for plant height with maximum $3.111 \mathrm{~m}$ and minimum $2.767 \mathrm{~m}$ in $\mathrm{Zn}_{5}$ and $\mathrm{Zn}_{1}$ respectively. Nearly same results for maximum height were achieved by treatments $\mathrm{Zn}_{6}$ and $\mathrm{Zn}_{7}$. The detailed results for all foliar application of zinc are given in Table 3 . The study clearly implies that the increment in foliar application of zinc directly increases the plant height which means that they are directly proportional to each other. The present finding is in agreement with the findings of [7] in guava.

\subsection{Length of fruit}

Different rates of foliar application of zinc had a very positive effect on length of Guava fruit as shown in Table 3. From the obtained results it is clear that length of fruit increased with the increase in Zinc treatment rates. The length of fruit was maximum $6.989 \mathrm{~cm}$ for $\mathrm{Zn}_{5}$ and minimum $6.272 \mathrm{~cm}$ for $\mathrm{Zn}_{0}$ respectively. However, near about same results for maximum fruit length was achieved by $\mathrm{Zn}_{6}$ and $\mathrm{Zn}_{7}$ treatments. The present finding is in agreement with [12] in guava.

\subsection{Breadth of fruit}

Statistically considerable results were observed for breadth of fruit as shown in Table 3. Maximum $6.070 \mathrm{~cm}$ and minimum 5.222 $\mathrm{cm}$ for breadth of fruit were recorded in $\mathrm{Zn}_{5}$ and $\mathrm{Zn}_{0}$ treatments respectively. Once again for the breadth of fruit same observation was noted with COV $6.454 \%$. The discussed findings are in accordance with [8] in guava.

\subsection{Weight of fruit}

The application of proper plants nutrients can boost up the growth of guava plant which eventually increases the weight of fruits per plant accordingly. According to the obtained results it had been observed that maximum 111.555 gm weight per fruit were recorded in $\mathrm{Zn}_{5}$ and minimum $80.689 \mathrm{gm}$ weight per fruit were recorded in control $\mathrm{Zn}_{0}$. The similar findings were also reported by [5] in guava.

\subsection{Number of fruits per plant}

During the research study it had been observed that maximum number of fruit 379.679 was noted in $\mathrm{Zn}_{5}$, while minimum 295.970 
fruits per plant was observed in $\mathrm{Zn}_{0}$ (control). The detailed results for all foliar application of zinc are given in Table 3. Once again for the number of fruits per plant same observations were noted with COV $29.482 \%$ and SE \pm 9.989 respectively. The present finding is in agreement with [11] for guava.

\subsection{Fruit yield}

On the basis of conducted study and statistical analysis of all harvesting operations it had been observed that foliar application of different rates of Zinc fertilizer had a positive effect on the yield $\mathrm{kg} /$ plant with COV $12.827 \%$ and SE \pm 4.343 accordingly. Maximum yield was found to be $41.935 \mathrm{~kg}$ / plant when fertilized with treatment $\mathrm{Zn}_{5}$. Likewise the minimum production was recorded in control $23.644 \mathrm{~kg}$ per plant for treatment $\mathrm{Zn}_{0}$. The similar findings were also reported by [10] for guava.

Table3. Effect of different Zinc concentration on fruit quantity parameters of guava.

\begin{tabular}{|c|c|c|c|c|c|c|}
\hline $\begin{array}{c}\text { Treatmen } \\
\mathbf{t}\end{array}$ & $\begin{array}{c}\text { Plant } \\
\text { Heigh } \\
\text { t }\end{array}$ & $\begin{array}{c}\text { Lengt } \\
h \text { of } \\
\text { Fruit }\end{array}$ & $\begin{array}{c}\text { Breadt } \\
h \text { of } \\
\text { Fruit }\end{array}$ & $\begin{array}{c}\text { Weight } \\
\text { of } \\
\text { Fruit }\end{array}$ & $\begin{array}{c}\text { Numbe } \\
\text { r of } \\
\text { fruits } \\
\text { per } \\
\text { plant }\end{array}$ & $\begin{array}{l}\text { Fruit } \\
\text { yield }\end{array}$ \\
\hline & $\mathrm{m}$ & $\mathrm{cm}$ & $\mathrm{cm}$ & gm & & $\begin{array}{l}\mathrm{kg} / \\
\text { plant }\end{array}$ \\
\hline $\mathrm{Zn}_{0}$ & 2.767 & 6.272 & 5.222 & 80.689 & 295.970 & $\begin{array}{c}23.64 \\
4\end{array}$ \\
\hline $\mathrm{Zn}_{1}$ & 2.778 & 6.333 & 5.414 & 86.618 & 315.039 & $\begin{array}{c}27.01 \\
8\end{array}$ \\
\hline $\mathrm{Zn}_{2}$ & 2.808 & 6.393 & 5.616 & 88.234 & 326.260 & $\begin{array}{c}28.50 \\
2\end{array}$ \\
\hline $\mathrm{Zn}_{3}$ & 2.858 & 6.464 & 5.686 & 90.597 & 334.845 & $\begin{array}{c}30.03 \\
7\end{array}$ \\
\hline $\mathrm{Zn}_{4}$ & 3.111 & 6.989 & 6.070 & $\begin{array}{c}111.55 \\
5\end{array}$ & 379.679 & $\begin{array}{c}41.93 \\
5\end{array}$ \\
\hline $\mathrm{Zn}_{5}$ & 3.091 & 6.595 & 5.939 & $\begin{array}{c}107.92 \\
9\end{array}$ & 351.046 & $\begin{array}{c}37.51 \\
1\end{array}$ \\
\hline $\mathrm{Zn}_{6}$ & 3.070 & 6.595 & 5.808 & $\begin{array}{c}100.96 \\
0\end{array}$ & 335.552 & $\begin{array}{c}33.54 \\
2\end{array}$ \\
\hline $\mathrm{Zn}_{7}$ & 2.990 & 6.464 & 5.737 & 93.021 & 336.764 & $\begin{array}{c}31.01 \\
7\end{array}$ \\
\hline $\mathrm{Zn}_{8}$ & 2.909 & 6.464 & 5.737 & 90.708 & 338.956 & $\begin{array}{c}30.44 \\
1\end{array}$ \\
\hline $\mathrm{SE}(\mathrm{m}) \pm$ & 0.172 & 0.253 & 0.212 & 10.878 & 9.989 & 4.343 \\
\hline $\begin{array}{c}\text { LSD } \\
(\mathrm{p}<0.05) \\
\end{array}$ & NS** & NS** & NS & NS & NS & NS \\
\hline $\operatorname{COV}(\%)$ & 9.817 & 6.706 & 6.454 & 12.938 & 29.482 & $\begin{array}{c}12.82 \\
7\end{array}$ \\
\hline
\end{tabular}

* Means followed by different letter shows significant result at $5 \%$ level of significance.

\subsection{Fruit Quality Parameters}

The chemical fruit quality in terms of maximum total soluble solids $9.373 \%$, minimum acidity $0.485 \%$, Vitamin C $(45.147 \mathrm{mg}$ per $100 \mathrm{ml}$ of juice) and firmness $5.969 \mathrm{~kg} / \mathrm{cm}^{2}$ were recorded with treatment $\mathrm{Zn}_{5}$ whereas, lowest total soluble solids $9.080 \%$, maximum acidity $0.586 \%$, Vitamin C $(25.078 \mathrm{mg}$ per $100 \mathrm{ml}$ of juice) and firmness $3.808 \mathrm{~kg} / \mathrm{cm}^{2}$ were recorded in treatment $\mathrm{Zn}_{0}$ control. These results are in accordance with [6] and [11] in Guava.

\section{Conclusions}

The subject study clearly pointed out that Zinc foliar application remarkably increase the yield and quality of Guava fruit. Amongst different concentration of $\mathrm{Zinc}, \mathrm{Zn}_{5}(0.5 \%)$ was ob-
Table 4. Effect of different Zinc concentration on fruit quality parameters of guava.

\begin{tabular}{|c|c|c|c|c|}
\hline \multirow{2}{*}{ Treatment } & \multicolumn{4}{|c|}{ Fruit Quality Parameters } \\
\cline { 2 - 5 } & TSS & Acidity & Vitamin C & Firmness \\
\hline \multirow{2}{*}{$\%$} & $\%$ & $\begin{array}{c}\text { (mg per 100 } \\
\text { ml of juice) }\end{array}$ & $\mathrm{kg} / \mathrm{cm}^{2}$ \\
\hline $\mathrm{Zn}_{0}$ & 9.080 & 0.586 & 25.078 & 3.808 \\
\hline $\mathrm{Zn}_{1}$ & 9.312 & 0.545 & 28.846 & 4.767 \\
\hline $\mathrm{Zn}_{2}$ & 9.474 & 0.515 & 30.250 & 4.515 \\
\hline $\mathrm{Zn} 3$ & 9.242 & 0.495 & 27.593 & 5.020 \\
\hline $\mathrm{Zn} \mathrm{n}_{4}$ & 9.373 & 0.485 & 45.147 & 5.969 \\
\hline $\mathrm{Zn} 5$ & 9.332 & 0.566 & 25.078 & 4.737 \\
\hline $\mathrm{Zn} 6$ & 9.575 & 0.495 & 43.895 & 4.959 \\
\hline $\mathrm{Zn} 7$ & 9.534 & 0.475 & 37.623 & 4.747 \\
\hline $\mathrm{Zn} 8$ & 9.373 & 0.566 & 35.108 & 4.141 \\
\hline $\mathrm{SE}(\mathrm{m}) \pm$ & 0.364 & 0.495 & 4.646 & 2.121 \\
\hline $\begin{array}{c}\mathrm{LSD} \\
(\mathrm{p}<0.05)\end{array}$ & $\mathrm{NS}$ & $\mathrm{NS}$ & $\mathrm{NS}$ & $\mathrm{NS}$ \\
\hline $\mathrm{COV}(\%)$ & 6.656 & 20.432 & 24.371 & 33.754 \\
\hline
\end{tabular}

* Means followed by different letter shows significant result at $5 \%$ level of significance.

served to be more suitable and economical dose as the fruit yield in terms of plant height $(3.111 \mathrm{~m})$, length of fruit $(6.989 \mathrm{~cm})$, breadth of fruit $(6.070 \mathrm{~cm})$, weight of fruit $(111.555 \mathrm{gm})$, number of fruits per plant (379.679), fruit yield (41.935 kg/plant) was recorded maximum. Same treatment also showed the superior fruit quality traits evaluated in terms of TSS $(9.373 \%)$, Vitamin C (45.147 $\mathrm{mg}$ per $100 \mathrm{ml}$ of juice), and Firmness $(5.969 \mathrm{~kg} / \mathrm{cm} 2)$ with lower acidity $(0.485 \%)$. Nearly same results were achieved by $\mathrm{Zn}_{6}(0.6 \%)$ and $\mathrm{Zn}_{7}(0.7 \%)$ concentration but statistical some parameters recorded less.

However, control plants showed un-satisfactory results regarding all the parameters. Too low or high Zinc concentration can reduced the yield and yield parameters of guava. From the obtained statistical results it can be concluded that the $0.5 \%$ micronutrient Zinc solution concentration has a best suited dose to increase the Guava yield in the arid region of Gharo, Sindh Pakistan. However, further investigation is necessary to establish the present findings in other regions of Pakistan with Guava and other fruits.

\section{Acknowledgment}

The authors wish to express their gratitude to Mr. Farukh Mazhar the owner of the Gharo model farm for allowing this research to be carried out on his farm, to the staff of the farm especially to Mr. Allah Bakhsh the farm supervisor, Mr. Mazhar Iqbal Sheikh for his kind assistance throughout the study, and all other individuals who have been source of help throughout the research period. 


\section{References}

[1] A. Asad, "Foliar fertilizers - fast acting agents". The Daily Dawn Newspaper article 2005.

[2] A. U. Bala, R.S. Chadra, Y.N. Reddy, "Effect of pre-harvest sprays of zinc and planting time on flowering, flower quality and Vase life of Gladiolus cultivars", J. Res. Angrau, 34(1), 8-12, 2006.

[3] A. El-Aal, A.M. Shaheen, A.A. Ahmed, A.R. Mahmoud, "Effect of foliar application of urea and amino acids mixtures as antioxidants on growth, yield and characteristics of squash”. Res. J. Agric. Bio. Sci., 6(1) 583-588, 2010.

[4] A.K. Fageria, M.P.B. Filhoa, A. Moreirab, C.M. Guimaresa, "Foliar fertilization of crop plants". J. Plant Nutri., 32(1), 1044-1064, 2009.

[5] A. Chandra, P. C. Jindal, "Sustainable fruit production in arid regions for export". Current Agric., 25(1-2), 13-16, 2001.

[6] I. Arshad, "Integrated application of NPK fertilizers on the growth and yield of guava (Psidium Guajava L.) in an arid region of lower Sindh, Pakistan". Int. Res. J. Plant \& Crop Sci., 2(1), 019-023, 2015.

[7] J. N. Khan, A. K. Jain, Rakesh Sharda, NavPrem Singh, P. P. S. Gill, Sumanjeet Kaur, "Growth, yield and nutrient uptake of guava (Psidium Guavaja L.) affected by soil matric potential, fertigation and mulching under drip irrigation". Agric. Eng. Int., 15(3), 3 17, 2013.

[8] L. M. José, D. José, P. Neto, D. Fernandes, "Response functions of the guava to water depth and nitrogen fertilization", Brazil. Mag. Fruit Cul., 29(2), 323$328,2007$.

[9] M. Kashif, K. Rizwan, M.A. Khan, A. Younis, "Efficacy of macro and micronutrients as foliar application on growth and yield of Dahlia hybrida L.". Int. J. Chem. Biochem. Sci., 5(1) 6-10, 2014.

[10] R. Ramniwas, A. D. K. Kaushik, S. P. Sarolia, V. Sin, "Effect of irrigation and fertigation scheduling on growth and yield of guava (Psidium guajava L.) under meadow orcharding”. Afri. J. Agric. Res., 7(47) 6350-6356, 2012.

[11] S. Sharma, S. K. Patra, R. Ray, "Effect of drip fertigation on growth and yield of guava". J. Enviro. \& Ecology, 29(1) 34-38, 2011.

[12] T. Kaur, "Effect of NPK fertilization on tree growth fruit yield and quality of sardar guava". M. Sc.Thesis, Punjab Agricultural University, Ludhiana, 2002. 